\title{
DEVELOPMENT STRATEGY OF STUDY PROGRAMS IN HIGHER EDUCATION TO RESPOND THE FOURTH INDUSTRIAL REVOLUTION: SWOT ANALYSIS
}

\author{
Devi Krisnawati, Rahmawan Tari Dhistianti Mei, Ayu Puspitaningtyas \\ University of Krisnadwipayana, Indonesia \\ *E-mail: dhistianti@unkris.ac.id
}

\begin{abstract}
SWOT analysis is a technique used to analyze the strengths, weaknesses, opportunities and threats of the institution, not only in business management area, but also in education field, especially in order to respond the fourth industrial revolution era. The research area was located in one of the study program of private university at Jakarta and SWOT analysis tool was used to evaluate the internal and external environment. Based on the findings, with matrix score of EFE is 2.51 and IFE 2.34, the positioning of study program is in a favorable situation with coordinate $(0,37 ; 0,435)$ in quadran 1 , SO strategy is strongly recommended to captured a potential opportunities and maximizing the internal strength to become a driving force of an aggressive growth. The recommended strategy contained in a form of collaboration with external parties (industries \& experts) in terms of producing a curriculum that relevant with the latest issue and helping the industry to create an innovation needed.
\end{abstract}

\section{KEY WORDS}

SWOT analysis, strategy, education, innovation, fourth industrial revolution.

The development of science and technology has changed the world, so that the phenomenon that occurs is no longer a big prey on the small but more to the fast can prey on the slow. The industrial world has undergone a change in response to changes in the global world, as when the first generation revolution carved history when human and animal power was replaced by the emergence of machines, as happened in the 18th century as the emergence of a steam engine, this caused an increase in the economy which has resulted in a six-fold increase in the average per capita income of countries in the world. After the steam engine, the presence of a power plant and combustion chamber emerged, which was the hallmark of the second generation revolution, so that at that time telephones, cars, airplanes began to appear. The third generation revolution began to be marked by the emergence of digital technology and the Internet, thus enabling the automation process. During this time, the world began to enter the gates of the fourth generation industrial revolution when digitalization emerged and formed a new pattern of disruptive technology that was so fast that many victims were killed by giant corporations, and technological change had eliminated jobs much faster than creating jobs (Brynjolfsson \& McAfee, 2014).

According to the Industry 4.0 concept, the Fourth Industrial Revolution dawned through the use of cyber-physical systems (CPSs), the Internet of Things (IOT), and services (Klaus, 2015). It also includes smart factories, cyber-physical systems, self organization, new systems in distribution and procurement, new systems in the development of products and services, adaptation to human needs and corporate social responsibility. Therefore, the Fourth Industrial Revolution features the creative connection between technology and the market in all industries based on IT, so the characteristics can be defined only when technical innovation is combined with institutional innovation as in the Second Industrial Revolution.

Entering the industry revolution 4.0 with the rapid growth and development of science, not only large companies must be sensitive and introspect in order to be able to quickly adjust the changes that occur and detect their position amid market competition. This also has to be done by universities. Improving the quality, quantity and distribution of human resources is an investment that must be fulfilled by all institutions involved in the field of education and training in facing this era. Universities that are formal institutions in the 
education sector are required to produce competent workers who are ready to face the growing era of industry, because the readiness of human resources is one of the capitals to meet the industry 4.0 eras. Higher education also has a big impact on people's lives because it influences the mindset of students, where in the future they will determine the direction of economic development and growth through their decision-making processes in the business and working environment.

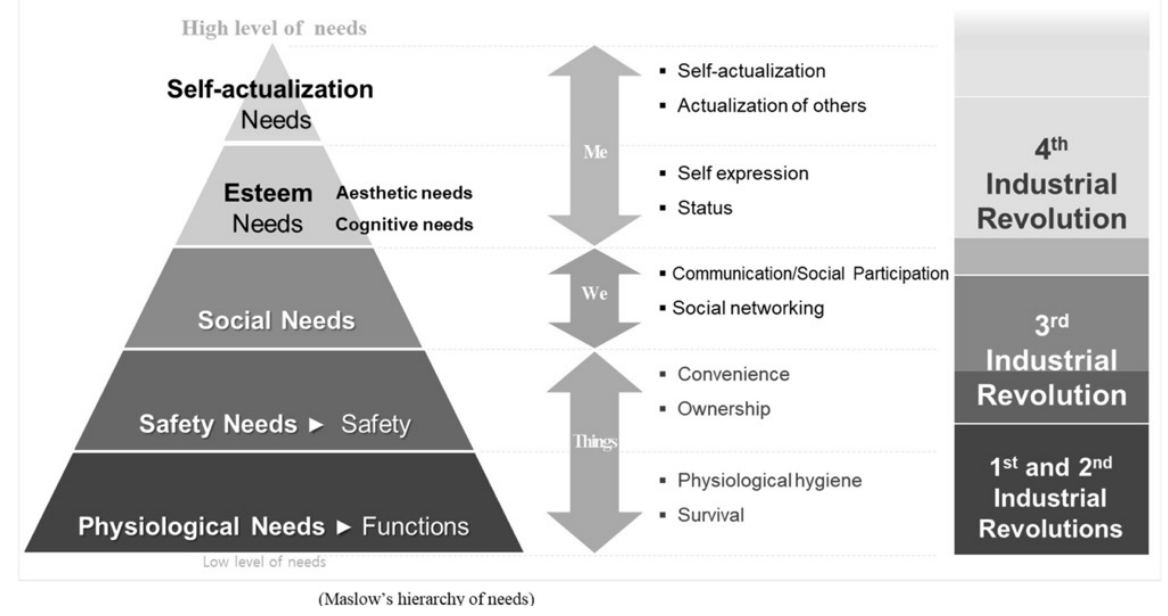

Figure 1 - Maslow's Hierarchy

Universities through its programs study respond to the needs of the community, by making the program study as a forum for the development of self-capacity and undergraduate competencies in certain fields that are in accordance with the typical knowledge of the study program. In particular, the management of program study plays a role in organizing education in the field of management in a professional manner that has competitive advantages, especially in the field of entrepreneurship. This program study is present to help improve the quality of life of the community through the provision of facilities and teaching models that adjust market demands and needs. So that it is expected to produce a workforce that has an intelligent mindset, professional and competent attitude in the world of work, as a decision maker both within a company and the development of new businesses that can absorb a lot of educated workforce. In its implementation, the management of program study is faced with several opportunities and challenges both internally and externally, so that to determine its readiness and its position in market competition, the program study must also conduct self-introspection in a sustainable manner to identify what strengths can be used as fuel and weaknesses. Realizing how fast this industrial revolution is coming which directly influences the efforts and readiness of all formal institutions in the field of education and training, in particular the management of program study, it is necessary to conduct research to identify the factors that have and must be possessed by the study program so as to produce and apply the best strategy and model that can be used to survive and excel in market competition.

\section{LITERATURE REVIEW}

SWOT Analysis is an analytical method that can be used by decision maker to identify various factors systematically, so as to formulate a best strategy, this analysis is based on a logic that can simultaneously maximize strengths \& opportunities and minimize weaknesses $\&$ threats. Through this analysis, the company and all the decision makers get references to events and information that has occurred and anticipate a problem that will or happening by making the best solution (Nouri et al., 2008). By getting information from conducting environmental analysis, and dividing it into internal and external factors, this analysis will help 
a company and decision makers achieve their goals, and anticipate or minimize the challenges ahead in achieving expected goal (Singh, 2010).

Table 1 - SWOT analysis matrix (Whalley, 2010)

\begin{tabular}{ccc}
\hline Strengths & Weaknesses \\
\hline Opportunities & $\begin{array}{c}\text { How do I use these strengths to take } \\
\text { advantage of these opportunities? }\end{array}$ & $\begin{array}{c}\text { How do I overcome the weaknesses } \\
\text { that prevent me from taking advantage } \\
\text { of these opportunities? }\end{array}$ \\
\hline Threats & $\begin{array}{c}\text { How do I use my strengths to reduce } \\
\text { the imnart nf threatc? }\end{array}$ & $\begin{array}{c}\text { How do I address the weaknesses that } \\
\text { will make these threats a reality? }\end{array}$
\end{tabular}

SWOT analysis aims to evaluate the internal strengths and weaknesses of a system, in the other hand, it also asses the environmental opportunities and threats. The SWOT model gives a systematic analysis for the recognition of each factor and also for the choice of a strategy that establish the best symmetry among them. Shariatmadari et al. (2013) stated that there are 4 strategies resulting from SWOT analysis. S-O strategies pursue opportunities that are a good fit to the company's strengths. W-O strategies overcome weaknesses to pursue opportunities. S-T strategies identify ways that the firm can use its strengths to reduce its vulnerability to external threats. W-T strategies establish a defensive plan to prevent the firm's weaknesses from making it highly susceptible to external threats. below:

Ifediora et al (2014) describe brief explanation about four factors which are given

Strengths are the qualities that enable managers to accomplish the institution's mission, which consider to be a characteristics within the organization that are important to the execution and ultimate success of the institution.

Weaknesses, have to do with the internal factors that could prevent the achievement of a successful result to the institution, it also influence the organizational success and growth. Weaknesses are controllable; it must be minimized and eliminated. In an institutions, it might appear as an insufficient facilities, lack of skilled staffs, lack of teacher/lecturer skills, etc.

Opportunities have to do with external elements that will prove helpful in achieving the goals set for the institute. These will arise when an institute can take benefit or conditions in its environment to plan and execute strategies that enable it to become more profitable. Opportunities can come in the form of the best prospects, competitive advantage and good match with what we have to offer.

Threats, it's uncontrollable and arise when conditions in eternal environment jeopardize the reliability and profitability of the institution. Among the possible threats that will be critical to any analysis is a negative public image, ever changing technology, competitive behavior, etc.

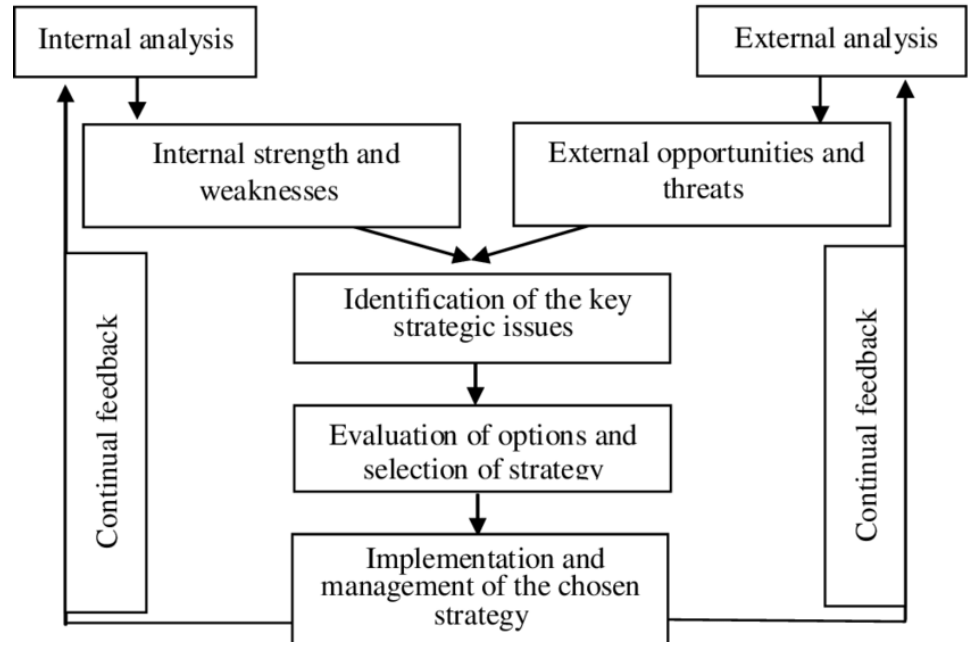

Figure 2 - The process of SWOT (Riston, 2008) 
Although the SWOT analysis originally intended for use in business applications, but the idea of using this tool in educational settings is not altogether new. Thomas et al (2014) suggested that this approach to increase minority enrolment in community and other regional colleges. The management tools also, can frequently be tailored for application in education. SWOT analysis can be used as a high-level and critical thinking exercise for students (Orr, 2013). There's also a relationship in student's opinion between a study program and their chances on the labor market (Fischer and Lipovska, 2014).

Hinton (2012) stated that SWOT analysis, which is consider as a preliminary decisionmaking technique, is one of the devices of strategic planning that helps institutions managers to evaluate the strengths, weaknesses, opportunities and threats involved in any business enterprise. Khamova (2013) also conducted a study to identify the weaknesses in the process of English language teaching in Moskow and apply new methods to transform them into strengths. Razmjoo and Nouhi (2014) also used SWOT analysis to evaluate junior high school English program in Iran and concluded that the program more suffers from weaknesses and is threatened by several threats than it enjoys the strength or takes advantage of the opportunities.

\section{METHODS OF RESEARCH}

This research is a quantitative and descriptive-survey in terms of research type, as in a descriptive study, the data is based on primary and original data for example a questionnaire (Brown, 1995). The researcher collected and analyzed data quantitavely. The location of the study was done in one of the study programs at private universities in Jakarta, namely Universitas Krisnadwipayana, this university was chosen because within a period of 3 years the number of students had grown quite well.

The participants of this study both were students in a $5^{\text {th }}$ semester and above at management study program and 25 lecturers, aged between 27 and 55, that represent of the accessible population since they had enough experience. In this research, the following phases of analysis were used are:

- Designing external and internal factors matrix;

- Analyzing TOWS matrix and SWOT diagram.

This analysis is basically an interaction from the result of internal factor evaluation analysis (EFI) and external factor evaluation (EFE), when it applied accurately, these simple assumptions have a huge impact on the design of a successful strategy (Soesilo, 2000).

\section{RESULTS OF STUDY}

Designing external and internal factors matrix. A list of external factors were gathered and divided into two groups, which are opportunities and threats. Weight is assigned to each factor and the value of each is between 0 and 1 . Zero (0) means the factor is not important, while one (1) means the factor is the most influential and critical. However, the total value of all weights put together should equal 1 . Rating is assigned to each factor, it indicates how effective the institutions current strategies respond to the factor, it scale between 1 and 4 . Rating captured whether the factor represented a major threat (rating $=1$ ), a minor threat (rating $=2$ ), a minor opportunity (rating $=3$ ), or a major opportunity (rating $=4$ ). If rating scale 1 to 4 was used, then opportunities must receive a 4 or 3 rating and threat must receive a 1 or 2 rating. The table 2 showed that: a large number of government and private sector scholarship, the increasing growth of productive age, the emerge of big data and analytical analysis for business management decision making, the industry revolution 4.0 and government work program to improve competitiveness through human resource quality, each by the score are 0,$04 ; 0,07 ; 0,06 ; 0,05$; and 0,06 , shared the first place (rating $=4$ ) of the opportunities table. While among the threats, the emerge of many new private universities that have excellent management study programs, increasing number of excellent international undergraduate program in management and a virtual learning environment in educational technology, each by the score of 0,$15 ; 0,08$; and 0,06 , were in the first place 
(rating $=2$ ) respectively. Based on the result of the EFE matrix result, the external factor for management study program has a value of 2,51.

Table 2 - External factors evaluation (EFE) matrix

\begin{tabular}{|c|c|c|c|c|}
\hline$n / n$ & External Factors & Weight & Rating & $\begin{array}{c}\text { Weighted } \\
\text { Score }\end{array}$ \\
\hline \multirow{9}{*}{ Opportunities } & $\begin{array}{l}\text { High industry demand for skilled, creative, innovative and } \\
\text { cognitive flexibility labor requirements }\end{array}$ & 0,05 & 3 & 0,15 \\
\hline & Increasing number of high school graduate in Bekasi area & 0,06 & 3 & 0,18 \\
\hline & $\begin{array}{l}\text { Increasing demand of company requirement for undergraduate } \\
\text { staff in Bekasi area }\end{array}$ & 0,08 & 3 & 0,24 \\
\hline & Large number of government and private sector scholarship & 0,04 & 4 & 0,16 \\
\hline & The increasing growth of productive age & 0,07 & 4 & 0,28 \\
\hline & $\begin{array}{l}\text { The emerge of big data and analytical analysis for business } \\
\text { management decision making }\end{array}$ & 0,06 & 4 & 0,24 \\
\hline & Industry revolution 4.0 & 0,05 & 4 & 0,2 \\
\hline & $\begin{array}{l}\text { Government work program to improve competitiveness through } \\
\text { human resource quality }\end{array}$ & 0,06 & 4 & 0,24 \\
\hline & 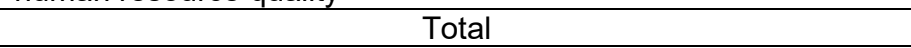 & 0,47 & & 1,69 \\
\hline \multirow{5}{*}{ Threats } & $\begin{array}{l}\text { The emerge of many new private universities that have } \\
\text { excellent management study programs }\end{array}$ & 0,15 & 2 & 0,3 \\
\hline & $\begin{array}{l}\text { The rise of promotional activities from competing universities } \\
\text { that emphasize, not only general but, specific matters regarding } \\
\text { academic excellence }\end{array}$ & 0,24 & 1 & 0,24 \\
\hline & $\begin{array}{l}\text { Increasing number of excellent international undergraduate } \\
\text { program in management }\end{array}$ & 0,08 & 2 & 0,16 \\
\hline & A virtual learning environment in educational technology & 0,06 & 2 & 0,12 \\
\hline & Total & 0,53 & & 0,82 \\
\hline & Total Weighted Score & 1,00 & & 2,51 \\
\hline
\end{tabular}

Table 3 - Internal factors evaluation (IFE) matrix

\begin{tabular}{|c|c|c|c|c|}
\hline$n / n$ & Internal Factors & Weight & Rating & $\begin{array}{l}\text { Weighted } \\
\text { Score }\end{array}$ \\
\hline \multirow{9}{*}{ Strengths } & Accessible location & 0,06 & 3 & 0,18 \\
\hline & Sister school relationship program for collaboration & 0,05 & 4 & 0,2 \\
\hline & Having sufficient and component lecturers in their fields & 0,05 & 4 & 0,2 \\
\hline & Strong support from alumni role & 0,04 & 3 & 0,12 \\
\hline & $\begin{array}{l}\text { Has adequate facilities \& infrastructure such as computer } \\
\text { library, investment gallery, language library, WIFI network, } \\
\text { library with the latest books for supporting students } \\
\text { competencies }\end{array}$ & 0,05 & 4 & 0,2 \\
\hline & Latest academic system and new blended learning method & 0,04 & 4 & 0,16 \\
\hline & Conducted the international undergraduate program & 0,05 & 4 & 0,2 \\
\hline & Installment tuition fees & 0,07 & 4 & 0,28 \\
\hline & Total & 0,41 & & 1,54 \\
\hline \multirow{5}{*}{ Weaknesses } & $\begin{array}{l}\text { General promotion content such as facilities, location, } \\
\text { alumni support, etc. }\end{array}$ & 0,18 & 1 & 0,18 \\
\hline & $\begin{array}{l}\text { Current budget implementation for operational activities } \\
\text { and infrastructure development }\end{array}$ & 0,09 & 2 & 0,18 \\
\hline & Apprenticeship collaboration program still in middle stage & 0,12 & 2 & 0,24 \\
\hline & $\begin{array}{l}\text { Students participation in both national and international still } \\
\text { in a field of non academic }\end{array}$ & 0,20 & 1 & 0,2 \\
\hline & Total & 0,59 & & 0,8 \\
\hline & Total Weighted Score & 1,00 & & 2,34 \\
\hline
\end{tabular}

IFE matrix weight ranged from 0 to 1 for each factor, zero means not important, while one indicates very important. The experts then rated of each item with a scale from 1 to 4 , that is, a major weakness (rating $=1$ ), a minor weakness (rating $=2$ ), a minor strength (rating $=3$ ), or major strength (rating $=4$ ). In order to calculate its weighted score, each importance factor was multiplied by its rating. In table 3 , among strength, accessible location and strong support from alumni role, (each by the score are 0,06 and 0,04 ) shared the first place (rating $=3$ ). While among the weaknesses, general promotion content (facilities, location, alumni 
support, etc) and students participation in both national \& international still in a field of non academic (each by the score are 0,18 and 0,20 ) are shared the first place (rating $=1$ ). The total value of internal factor evaluation (IFE) matrix is 2,34.

\section{Analyzing TOWS Matrix:}

Table 4 - TOWS Matrix

\begin{tabular}{|c|c|c|c|}
\hline & Strengths & Weaknesses \\
\hline & & $\begin{array}{l}\text { S1: Accessible location } \\
\text { S2: Sister school relationship program } \\
\text { for collaboration } \\
\text { S3: Having sufficient and component } \\
\text { lecturers in their fields } \\
\text { S4: Strong support from alumni role } \\
\text { S5: Has adequate facilities\& } \\
\text { infrastructure such as library, investment } \\
\text { gallery, language institution, WIFI } \\
\text { network, library with the latest books for } \\
\text { supporting students competencies } \\
\text { S6: Latest academic system and new } \\
\text { blended learning method } \\
\text { S7: Conducted the international } \\
\text { undergraduate program } \\
\text { S8: Installment tuition fees }\end{array}$ & $\begin{array}{l}\text { W1:General promotion content } \\
\text { such as facilities, location, } \\
\text { alumni support, etc. } \\
\text { W2:Current budget } \\
\text { implementation for operational } \\
\text { activities and infrastructure } \\
\text { development } \\
\text { W3:Apprenticeship } \\
\text { collaboration program still in } \\
\text { middle stage } \\
\text { W4:Students participation in } \\
\text { both national and international } \\
\text { still in a field of non academic }\end{array}$ \\
\hline & Interaksi $\mathrm{O}-\mathrm{S}-\mathrm{W}$ & SO & WO \\
\hline 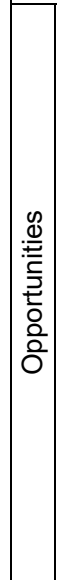 & $\begin{array}{l}\text { O1: High industry demand for skilled, } \\
\text { creative, innovative and cognitive flexibility } \\
\text { labor requirements } \\
\text { O2: Increasing number of high school } \\
\text { graduate in Bekasi area } \\
\text { O3: Increasing demand of company } \\
\text { requirement for undergraduate staff in } \\
\text { Bekasi area } \\
\text { O4: Large number of government and } \\
\text { private sector scholarship } \\
\text { O5: The increasing growth of productive age } \\
\text { O6: The emerge of big data and analytical } \\
\text { analysis for business management decision } \\
\text { making } \\
\text { O7: Industry revolution } 4.0 \\
\text { O8: Government work program to improve } \\
\text { competitiveness through human resource } \\
\text { quality }\end{array}$ & $\begin{array}{l}\text { Collaboration with Industrial world and } \\
\text { adding an industry relevant syllabus into } \\
\text { a curriculum in order to adjust the global } \\
\text { demand }\end{array}$ & $\begin{array}{l}\text { Preparing students both } \\
\text { academically and soft skills in } \\
\text { meeting industry needs, and } \\
\text { also the active role of the faculty } \\
\text { in providing information is } \\
\text { needed regarding the } \\
\text { increasing demand level of } \\
\text { skilled labor in the industry to } \\
\text { motivate students }\end{array}$ \\
\hline & Interaksi T-S - W & ST & W T \\
\hline $\begin{array}{l}\frac{\mathscr{D}}{\mathbb{D}} \\
\stackrel{\Phi}{E} \\
\stackrel{F}{F}\end{array}$ & $\begin{array}{l}\text { T1:The emerge of many new private } \\
\text { universities that have excellent management } \\
\text { study programs } \\
\text { T2:The rise of promotional activities from } \\
\text { competing universities that emphasize, not } \\
\text { only general but, specific matters regarding } \\
\text { academic excellence } \\
\text { T3:Increasing number of excellent } \\
\text { international undergraduate program in } \\
\text { management } \\
\text { T4:A virtual learning environment in } \\
\text { educational technology }\end{array}$ & $\begin{array}{l}\text { Updating the concentration of study } \\
\text { programs, making promotional models } \\
\text { through alumni networks, developing } \\
\text { international classes that have been } \\
\text { owned by foreign institutional networks } \\
\text { and improving learning information } \\
\text { technology facilities }\end{array}$ & $\begin{array}{l}\text { Promoting outside the campus } \\
\text { area by highlighting } \\
\text { transportation flexibility to the } \\
\text { location, budget re-allocations } \\
\text { focused on academic } \\
\text { development, collaborating with } \\
\text { alumni for apprenticeship } \\
\text { programs, and providing } \\
\text { assistance to students to } \\
\text { compete in the academic } \\
\text { (scientific) field at the national } \\
\text { level }\end{array}$ \\
\hline
\end{tabular}

The above result of the interaction gave rise to 4 (four) choices of positioning strategies, namely:

(a). SO strategy, which is collaboration with Industrial world and adding an industry relevant syllabus into a curriculum in order to adjust the global demand.

(b). WO strategy, which is preparing students both academically and soft skills in meeting industry needs, and also the active role of the faculty in providing information is needed regarding the increasing demand level of skilled labor in the industry to motivate students

(c). ST strategy, which is updating the concentration of study programs, making promotional models through alumni networks, developing international classes that have been owned by foreign institutional networks and improving learning information technology facilities 
(d). WT strategy, which is promoting outside the campus area by highlighting transportation flexibility to the location, budget re-allocations focused on academic development, collaborating with alumni for apprenticeship programs, and providing assistance to students to compete in the academic (scientific) field at the national level

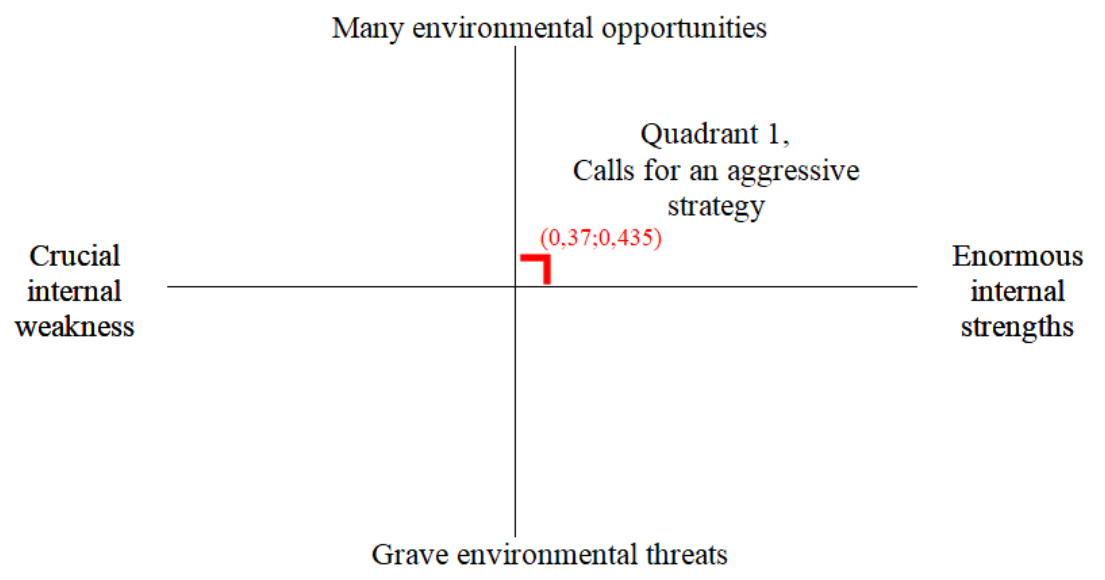

Figure 3 - SWOT Analysis Diagram

Based on the above result of matrix EFE and IFE, it is known that the external factor has a value of 2,51 and an internal factor value is 2,34 , with each score of the components are $\mathrm{S}$ (strength) is 1,$54 ; \mathrm{W}$ (weaknesses) is 0,$8 ; \mathrm{O}$ (opportunities) is 1,69 and $\mathrm{T}$ (threats) is 0,82 . Pearce and Robinson (1998) developed SWOT analysis calculation to determine the real organization position, which is:

- $S W=(S-W) / 2=(1,54-0,8) / 2=0,37$;

- $\mathrm{OT}=(\mathrm{O}-\mathrm{T}) / 2=(1,69-0,82) / 2=0,435$.

From that point, we know that study program position is in Quadrant 1 with coordinate $(0,37 ; 0,435)$.

\section{DISCUSSION OF RESULTS}

Matrix IFE indicates that the strategy implemented by the study program has not been perfect, because it has not been able to maximize the strength possessed, and minimize weaknesses. The main weakness at this time is the lack of activity levels to train and develop the academic abilities of students so that they are ready to take part in national and international competitions. With the high active role of students, this thing could be a key component in future promotion, all of these efforts, if it collaborating with the strengths they have, it will further strengthen their position in the era of competition at this time. Several main powers of this management study program have that will influence the company's internal factors the most namely; sister school relationship program for collaboration, having sufficient and component lecturers in their fields, has adequate facilities \& infrastructure for supporting students competencies, latest academic system \& new blended learning method and conducted the international undergraduate program.

Meanwhile, the EFE matrix indicates that the study program is slightly capable of dealing with the obstacles ahead, in addition to having a relatively good ability to capture opportunities. The main opportunity that can be utilized in improving the quality of students to be ready to face the changes in the industrial revolution 4.0 is to capture all government efforts to improve the competence of human resources in Indonesia, so that they are ready to face global competition, as has been done now by providing scholarships to aspiring productive age workforce candidates, collaboration with the industrial world and professionals to respond all the opportunities by developing and completing curricula and other educational programs so that it is relevant at this time of change, forming an institution that ensures graduates have the competencies needed to deal with job competition. By 
focusing on maximizing efforts to optimize opportunities ahead, the main challenges faced will be easily to handle.

\section{CONCLUSION}

From the results of processing data and information using the TOWS matrix and SWOT analysis diagram, it can be seen that the position of the study program is in quadrant 1 , where this position is a favorable situation, because it has a combination between opportunities and strength so it can take advantage of opportunities. The best strategy that strongly recommended applying in this condition is the SO strategy, which describe as a strategy that supports aggressive growth policies where the potential advantages possessed, in the form of internal strength factors, are maximized so that they can become a driving force to seize opportunities. By collaborating with external (industrial and professional) parties, a positive synergy will be formed for both parties, the study program participates in helping solve industrial problems through research so that the results will be useful (not just ending on a sheet of paper only), the latest capabilities and topics needed to conduct quality research can be included in teaching materials or curriculum so that students will naturally have an interest in the problems that the industry have faced. Meanwhile, with the results of quality research from universities, both industry and professionals, can come up with the best idea and innovation that will give a huge impact to the industry itself and society as a whole.

Limitations that exist in this study is on the selection of the study programs which have a superior accreditation and located in the capital city of Indonesia. The informant only provided some information on the weaknesses, so deeper investigation is needed. The result of the study are expected to be a model for other study programs which are still in developing stage, or having a good accreditation, and make them fully participate in the fourth industrial revolution.

\section{REFERENCES}

1. Brown, J. D. (1995). Understanding Research in Second Language Learning. New York: Cambridge University Press.

2. Brynjolfsson, E., \& McAfee, A. (2014). The second machine age: work, progress, and prosperity in a time of brilliant technologies. WW Norton \& Company.

3. Fischer, J. and Lipovská, H. (2014) 'The Work-study Dilemma of Czech Undergraduates', Journal on Efficiency and Responsibility in Education and Science, vol. 7, no. 3-4, pp. 4552. http://dx.doi.org/10.7160/eriesj.2014.070301.

4. Hinton, K. (2012). A Practical Guide to Strategic Planning in Higher Education. Society for College and University Planning (SCUP).

5. Ifediora, C., Idoko, O., \& Nzekwe , J. (2014). Organization's stability and productivity: the role of SWOT analysis an acronym for strength, weakness, opportunities and threat. International Journal of Innovative and Applied Research, 2(9), 23- 32.

6. Khamova, S. (2013). Weaknesses in the Process of English Language Teaching. International Journal of Humanities and Social Science, 3(20), 33-36.

7. Nouri J, Karbassi AR, Mirkia S (2008). Environmental management of coastal regions in the Caspian Sea. Int. J. Environ. Sci. Tech., 5(1): 43-52.

8. Orr, B. (2013) 'Conducting a SWOT Analysis for Program Improvement', US-China Education Review A, vol. 3, no. 6, pp. 381-384.

9. Razmjoo, S., \& Nouhi, N. (2014). A SWOT Analysis of the Junior High School English program: Grounded Theory Approach. International Journal of Language Learning and Applied Linguistics World, 5(1), 306-312.

10. Riston N (2008). Strategic Management. Neil Riston and Ventus Publishing APS, ISBN 978-87-7681-417-5.

11. Salusu, J., 2000. Pengambilan Keputusan Strategik untuk Organisasi Publik dan Nonprofit. Cetakan Ketiga. Jakarta; PT Gramedia Widiasarana Indonesia. 
12. Schwab, Klaus, "The Fourth Industrial Revolution: what it means and how to respond", World Economic Forum, 15 December 2015.

13. Shariatmadari, M., Sarfaraz, A., Hedayat, P. and Vadoudi, K. (2013) 'Using SWOT Analysis and Sem to Prioritize Strategies in Foreign Exchange Market in Iran', ProcediaSocial Behavioral Sciences, vol. 99, pp. 886-892. http://dx.doi.org/10.1016/j. sbspro.2013.10.561.

14. Singh N (2010). SWOT Analysis - A Useful Tool For Community Vision A concept paper of central Himalayan village. Res., 2(9): 16-18.

15. Soesilo, N.I. 2000. Manajemen Strategik di Sektor Publik (Pendekatan Praktis). Buku-II. Jakarta; Magister Perencanaan dan Kebijakan Publik (MPKP)-Fakultas EkonomiUniversitas Indonesia.

16. Thomas, S., Chie Q.T., Abraham, M., Jalarajan Raj, S. and Beh, L.S. (2014) 'A Qualitative Review of Literature on Peer Review of Teaching in Higher Education: An Application of the SWOT Framework', Review of Educational Research, vol. 84, no 1, pp. 112-159. http://dx.doi.org/10.3102/0034654313499617.

17. Whalley A (2010). Strategic Marketing. Andrew Whally and Ventus Publishing APS, ISBN 978-87-7681-643-8. 